\title{
VARIATION IN THE M-ANTIGEN OF GROUP-A STREPTOCOCCI
}

\author{
W. R. Maxted and H. A. Valkenburg \\ Streptococcus Reference Laboratory, Colindale, London, and \\ Department of Microbial Diseases, University Hospital, Leiden
}

\section{Plate XIX}

THE M-antigen is believed to be an important virulence-factor in group-A streptococci (Lancefield, 1962). Strains that possess an M-antigen will survive in normal human blood (Kuttner and Lenert, 1944) and kill mice when injected into them intravenously or intraperitoneally (Todd and Lancefield, 1928). In man, the presence of $\mathrm{M}$-antibody in the blood prevents clinical infection with streptococci that have the corresponding M-antigen, but not with members of other M-types (Wannamaker et al., 1953). Immunity to infection is therefore type-specific. Over 50 distinct M-antigens have been described, but with the single exception of strains with the two M-antigens 14 and 51 (Wiley and Wilson, 1961) only one M-antigen is found in each streptococcus.

Cultures of group-A streptococci may produce variants devoid of $\mathbf{M}$-antigen. This change may be observed in the laboratory when, in cultures consisting of " matt" colonies that give a precipitin reaction with a particular M-antiserum, " glossy" colonial variants arise that give no reaction with the antiserum; but loss of $\mathrm{M}$-antigen is by no means always associated with an obvious change in colonial form.

There have been reports of the apparent loss of M-antigen by streptococci in patients during convalescence (Rothbard and Watson, 1948; Wormald, 1956). The evidence for this was that the streptococci isolated in the acute stage of the illness gave a precipitin reaction with an $\mathrm{M}$-antiserum whereas those isolated later did not react with this serum. The possibility could not always be excluded that the original strain had been replaced by an unrelated streptococcus, but in at least one instance the M-positive and the M-negative organism had the same T-antigen.

A long-term study of streptococcal sore throat in the village of Voorhout in the Western Netherlands (Valkenburg et al., 1963) provided an opportunity to investigate the apparent loss of $\mathrm{M}$-antigen by a strain of group-A Streptococcus in a human population. The predominant streptococcus in the village appeared to be a member of type 12 according to its T-agglutination pattern. Organisms with this T-typing pattern increased greatly in frequency during the study, but only those isolated in the first $2 \mathrm{yr}$ had the M-antigen 12 (Valkenburg et al., 1967). Subsequent investigations showed that the streptococci with the T12 antigen but without the M12 antigen are not M-negative;

Received 6 Aug. 1968; accepted 24 Sept. 1968.

J. MED. MICROBIOL.-VOL. 2 (1969) 
they possess a different $\mathrm{M}$-antigen. There was also evidence that the new M-type had arisen from M-type 12.

\section{MATERIALS AND METHODS}

The field investigation. At the time of the investigation, medical care for the population of Voorhout was provided by one general practice. From May 1959, all patients seeking advice for acute sore throat were included in the investigation if they fulfilled a number of criteria (Goslings et al., 1963). A throat swab was collected at the first examination, and on the 10th and 30th days afterwards, when the first and second blood samples were also obtained.

Dry, untreated, cottonwool swabs were used, and were sent by mail to the laboratory in Leiden. The swabs were in the mail for varying periods and this may have influenced the yield of streptococci, but tests done with batches of swabs left for comparable times before plating showed that the proportion from which group-A streptococci were isolated was roughly the same (about 55 per cent.) for all the time-intervals chosen.

Isolation of streptococci. Swabs were stroked on the surface of plates of 5 per cent. defibrinated sheep-blood agar and were subsequently immersed in sheep blood broth. The cultures were incubated anaerobically overnight at $37^{\circ} \mathrm{C}$, and the blood broths were subcultured to blood-agar plates. Representative haemolytic colonies were subcultured and grouped serologically by Lancefield's method. All group-A streptococci were freeze-dried in a few drops of sterile sheep blood. Cultures of these strains were freshly redeemed and sent to Colindale on blood-agar slopes in screw-capped bottles for further study.

Only the group-A streptococci isolated at the first examination of each patient will be considered in this communication.

Typing. All the cultures of group-A streptococci were sent to Dr C. E. de Moor at the National Institute of Public Health, Utrecht, for typing by the T-agglutination method.

Most of these cultures were re-typed at Colindale. T-typing was repeated with a similar set of antisera, and M-precipitation typing was carried out with appropriate antisera according to the T-typing pattern. M-antisera for the following types were available: $1,2,3,5,6$, $9,11,12,14,15,17,18,19,22,23,24,25,26,28,29,30,31,33,36,37,39,41,43,46,47$, $48,49,50,51$ and 52; and for provisional types 53,54 and 55 . The methods used in the Streptococcus Reference Laboratory for the preparation of typing sera, and for $\mathrm{M}$ - and T-typing, were described by Williams (1958). M-antigens were generally detected by a precipitin test in capillary tubes (Swift, Wilson and Lancefield, 1943), but some tests were carried out by the double-diffusion method (Ouchterlony, 1949) in 1 per cent. Ionagar gel on slides.

\section{Group-A streptococci used in detailed studies included the following strains.}

No. 3621 and 3651: isolated from different patients in Voorhout during the 1st $\mathrm{yr}$ of the investigation. Both were agglutinated by the antiserum for T-type 12, and gave a precipitin reaction with the $\mathrm{M} 12$ antiserum $(\mathrm{T} 12+, \mathrm{M} 12+)$.

No. 3621 var. and 3651 var.: colonial variants selected respectively from no. 3621 and 3651 ; both were agglutinated by the antiserum for T-type 12, but did not give a precipitin reaction with the M12 antiserum (T12+, M12-).

No. 3489: a $\mathrm{T} 12+, \mathrm{M} 12$ - strain isolated from a patient in the $3 \mathrm{rd} \mathrm{yr}$ of the investigation.

No. 41448: a stock laboratory strain of type $12(\mathrm{~T} 12+, \mathrm{M} 12+)$.

No. NCTC8709, "type 6 glossy": used for absorption of M-type antisera to remove group antibody.

No. NCTC8305: M-type 24.

No. 294: M-type 2.

No. 100067: M-type 9.

No. K56: used as an indicator of lysogeny (see Kjems, 1958). 
Survival of streptococci in normal human blood. The ability of streptococci to survive in normal human blood was investigated by adding a small number of organisms to fresh heparinised blood from a volunteer known to be devoid of type-12 M-antibody. A 4-hr culture of the organisms in Todd-Hewitt broth was diluted so that $0.02 \mathrm{ml}$ contained between 200 and 500 colony-forming units. This volume was inoculated into $0.3 \mathrm{ml}$ of blood, which was placed in a sealed ampoule and incubated for $3-4 \mathrm{hr}$ at $37^{\circ} \mathrm{C}$ on a rotating drum. A measured quantity was then removed and used to prepare pour-plates of blood agar, which were incubated at $37^{\circ} \mathrm{C}$ overnight.

Indirect bactericidal test. A similar system, based on the method of Lancefield (1957), was used to observe the effect of antiserum on the survival of streptococci in normal human blood. A single dilution of the culture containing 50-500 colony-forming units in $0.02 \mathrm{ml}$ was incubated with $0.04 \mathrm{ml}$ antiserum and $0.3 \mathrm{ml}$ blood (see Maxted and Potter, 1967).

Serum opacity reaction. For the tube test, the streptococcus was inoculated heavily from a blood agar plate into tubes containing $2 \mathrm{ml}$ of serum-glucose broth (Wright's infusion broth to which 0.4 per cent. glucose and 5 per cent. horse serum had been added). The medium was incubated for $5 \mathrm{hr}$ at $37^{\circ} \mathrm{C}$ and the tube was then centrifuged and the supernatant discarded; $1 \mathrm{ml}$ of horse serum was added to the deposit and the tube was shaken; 2 drops of 1 per cent. thiomersal were added, and the tube was incubated for $18 \mathrm{hr}$ at $37^{\circ} \mathrm{C}$. After centrifugation, the supernatant was examined visually for opacity (fig. 1). When obvious opacity was present, the streptococcus was considered to give a positive serum opacity reaction (SOR +). A culture known to give no increase in opacity ( $\mathrm{SOR}-$ ) was included in each batch of tests.

In the plate test, $10 \mathrm{ml}$ of a melted agar medium consisting of Wright's broth with 0.4 per cent. glucose and 1.2 per cent. Davis agar was mixed thoroughly with an equal volume of horse serum at $50^{\circ} \mathrm{C}$. It was seeded with an appropriate dilution of an overnight broth culture of streptococci to give discrete colonies, and poured into a petri dish. The plates were incubated for $24 \mathrm{hr}$ at $37^{\circ} \mathrm{C}$, and then allowed to remain at room temperature for a further $24 \mathrm{hr}$. The colonies were examined for the presence or absence of a surrounding halo (see fig. 2).

Test for lysogeny. Streptococci were tested for the presence of phages that formed plaques on the indicator strain K56. The most consistent results were obtained when the cultures were grown in Wright's infusion broth containing 0.4 per cent. glucose and 5 per cent. horse serum, and on plates of the same medium solidified with 1.2 per cent. Davis agar. Broth was inoculated heavily with the strain to be tested for lysogeny, and was incubated for $5 \mathrm{hr}$ at $37^{\circ} \mathrm{C}$. After centrifugation, the supernatant was spotted on to a lawn made by flooding plates of the agar medium with a 5-hr broth culture of the strain K56.

\section{RESULTS}

\section{Prevalence of type-12 streptococci in Voorhout}

In the 5 yr beginning May 1959, 471 persons were seen with acute attacks of sore throat, and group-A streptococci were isolated from 294 of them ( 62 per cent.) at the first examination. The investigation was stopped in April 1962, because the original intention was that it should run for $3 \mathrm{yr}$ only, but the results of typing the cultures revealed such an interesting situation that it was re-started in November 1962 and continued until April 1964. The number of patients with sore throat, and the proportion of them from whom group-A streptococci were isolated, showed little change during the period of observation (table I). Streptococci of T-type 12 were seldom found during the 1 st yr, but later became very much more common; they were isolated from 8 per cent. of patients with sore throat in 1959-60, and from between 24 and 32 per cent. in each of the four succeeding years. 
Ninety-eight of the 111 cultures that had been agglutinated by the Tantiserum for type 12 were re-examined in London, and the result of the T-typing was confirmed in every case. When the cultures were examined in the precipitation test with type-12 $\mathrm{M}$-antiserum, however, it was found that members of M-type 12 had been isolated only in the first $2 \mathrm{yr}$ of the investigation (table I). All 9 of the cultures isolated in 1959-60, but only 3 of 18 of the 1960-61 cultures, and none of the 71 cultures isolated after May 1961, had the M-antigen 12.

Two possible explanations of these findings had to be considered; the original M-type 12 strain might have lost its M-antigen, or it might have been

TABLE I

Data relating to streptococci isolated from patients with acute sore throat in Voorhout during the period 1959-64

\begin{tabular}{l|c|c|c|c|c}
\hline Year & $\begin{array}{c}\text { Number of } \\
\text { patients } \\
\text { examined }\end{array}$ & $\begin{array}{c}\text { Number } \\
\text { yielding } \\
\text { group-A } \\
\text { streptococci }\end{array}$ & $\begin{array}{c}\text { Number } \\
\text { yielding } \\
\text { T-type-12 } \\
\text { streptococci }\end{array}$ & \multicolumn{2}{|c|}{ Number of T-type-12 streptococci } \\
\cline { 1 - 2 } & & further investigated & $\begin{array}{c}\text { found to have M12 } \\
\text { antigen }\end{array}$ \\
\hline $1959-60$ & 111 & $62(56) \dagger$ & $9(8) \dagger$ & 9 & $9(100) \dagger$ \\
$1960-61$ & 116 & $75(65)$ & $28(24)$ & 18 & $3(17)$ \\
$1961-62$ & 115 & $74(64)$ & $37(32)$ & 37 & 0 \\
$1962-63^{*}$ & 38 & $27(71)$ & $9(24)$ & 6 & 0 \\
$1963-64$ & 91 & $56(62)$ & $28(31)$ & 28 & 0 \\
\hline
\end{tabular}

* Five months only. $\quad \uparrow$ Percentage of number examined.

replaced by a second strain that happened to have the same T-antigen. In either case, the ability of a strain with no identifiable $\mathbf{M}$-antigen to initiate infection in large numbers of people was difficult to explain.

\section{Serological examination of apparently $M$-negative strains of type 12}

The twelve M-positive type-12 cultures isolated before May 1961 were plated on blood agar and examined for colonial variants. From three of them variants were selected that gave no precipitin reaction with type-12 M-antiserum and thus resembled the organism prevalent in later years.

Two of the cultures (no. 3621 and 3651) and their apparently M-negative variants (no. 3621 var. and 3651 var.) were examined in detail together with no. 3489 , a representative T12+, M12- culture isolated in 1963 . First, they were inoculated in small numbers into normal human blood, and all five survived and grew equally well. Indirect bactericidal tests were therefore performed by adding type-12 M-antiserum to the mixtures. The results of a representative experiment are given in table II; no. $3651(\mathrm{~T} 12+, \mathrm{M} 12+)$, and a laboratory stock culture of an M-type- 12 streptococcus were killed in the presence of type-12 M-antiserum, but no. 3489 (T12 +, M12-) was unaffected. A culture of M-type 24 and its homologous antiserum were included to show 
that the killing effect was type-specific. These results suggested that the $\mathrm{T} 12+, \mathrm{M} 12$ - variants of the $\mathrm{T} 12+, \mathrm{M} 12+$ cultures, and the cultures that were $\mathrm{T} 12+, \mathrm{M} 12-$ when first isolated, might possess an M-antigen other than 12.

Acid extracts of a representative group of $\mathrm{T} 12+, \mathrm{M} 12-$ cultures were therefore tested with all the available M-antisera for other types, but no significant precipitation reactions were obtained. If these organisms did possess an M-antigen, therefore, it was not likely to be one that had been described before.

Antisera were made with cultures no. $3651(\mathrm{~T} 12+, \mathrm{M} 12+)$ and no. 3489 $(\mathrm{T} 12+, \mathrm{M} 12-)$ by the intravenous injection of heat-killed suspensions into

TABLE II

Results obtained with 4 representative strains in the indirect bactericidal test with type-12 M-antiserum

\begin{tabular}{|c|c|c|c|c|c|}
\hline \multicolumn{3}{|c|}{ Streptococcus } & \multicolumn{3}{|c|}{$\begin{array}{l}\text { Degree of growtht observed in normal } \\
\text { human blood in the presence of }\end{array}$} \\
\hline Strain & $\begin{array}{l}\text { Antigenic } \\
\text { structure }\end{array}$ & $\begin{array}{c}\text { Number of } \\
\text { viable particles } \\
\text { in test } \\
\text { inoculum* }\end{array}$ & $\begin{array}{l}\text { normal } \\
\text { rabbit } \\
\text { serum }\end{array}$ & $\begin{array}{c}\text { type-12 } \\
\mathrm{M} \text {-antiserum }\end{array}$ & $\begin{array}{c}\text { type-24 } \\
M \text {-antiserum }\end{array}$ \\
\hline $\begin{array}{l}\text { Stock M-type } 12 \\
3651 \\
3489 \\
\text { Stock M-type } 24\end{array}$ & $\begin{array}{l}\text { T12+, M12+ } \\
\text { T12+, M12+ } \\
\text { T12+, M12- } \\
\text { T4+, M24+ }\end{array}$ & $\begin{array}{l}200 \\
170 \\
280 \\
140\end{array}$ & $\begin{array}{l}+++t \\
+++ \\
++t \\
+++\end{array}$ & $\begin{array}{c}3 \\
23 \\
+++ \\
+++\end{array}$ & $\begin{array}{l}+++ \\
+++ \\
++ \\
0\end{array}$ \\
\hline
\end{tabular}

* $0.02 \mathrm{ml}$ of a $10^{-3}$ dilution of a 5 -hr broth culture.

$\dagger$ Number of colonies from $0.02 \mathrm{ml}$ of mixture after incubation for $5 \mathrm{hr}$.

$\$$ Too numerous to count.

rabbits. After absorption with suspensions of a heterologous streptococcus (NCTC8709, type 6), the sera were tested for their ability to precipitate with acid extracts of streptococci and to enhance the specific killing of streptococci in the indirect bactericidal test.

The antiserum made with no. $3651(\mathrm{~T} 12+, \mathrm{M} 12+)$ behaved like an ordinary type-12 M-antiserum. It precipitated with extracts of the homologous culture and of the stock M-type-12 streptococcus, and it enhanced the bactericidal effect of human blood for both these cultures (table III). On the other hand, the antiserum prepared with no. 3489 (T12+, M12-) gave a weak precipitin reaction with extracts of the homologous organism, and with the T12+, M12variants obtained from the $\mathrm{T} 12+, \mathrm{M} 12+$ cultures. In the indirect bactericidal test it killed the homologous organism and 3651 var. (T12+, M12-) but had no effect on 3651 (T12+, M12+) or on the stock M-type-12 culture.

The precipitin reaction produced in capillary tubes by the antiserum to 3489 with homologous extract was disappointingly weak, but when the same serum and extract were tested by the double-diffusion method in agar gel a 
clear line of precipitation was seen which showed no reaction of identity with an M-type-12 antigen-antibody system included in the same test.

The 3489 antiserum also contained T-antibodies; it agglutinated trypsinised suspensions of all members of T-type 12, whether or not they formed the $\mathrm{M}$ antigen 12. No cross-reactions were seen when this serum was tested with trypsinised suspensions of strains of heterologous types. It appeared, therefore, that the T-antigen of the $\mathrm{T} 12+, \mathrm{M} 12$ - strains was indistinguishable from that of M-type-12 streptococci.

\section{TABLE III}

A comparison of the bactericidal effects of antisera made with $\mathrm{T12}+, \mathrm{M} 12+$ and with T12+, M12- cultures

\begin{tabular}{|c|c|c|c|c|c|c|c|}
\hline \multicolumn{3}{|c|}{ Streptococcus } & \multicolumn{5}{|c|}{$\begin{array}{l}\text { Degree of growthi observed in normal human blood } \\
\text { in the presence of }\end{array}$} \\
\hline Strain & $\begin{array}{l}\text { Antigenic } \\
\text { structure }\end{array}$ & $\begin{array}{c}\text { No. } \\
\text { of viable } \\
\text { particles } \\
\text { in test } \\
\text { inoculum* }\end{array}$ & $\begin{array}{c}\text { normal } \\
\text { rabbit } \\
\text { serum }\end{array}$ & $\begin{array}{l}\text { M12 } \\
\text { typing } \\
\text { serum }\end{array}$ & $\begin{array}{l}\text { antiserum } \\
\text { to } 3651\end{array}$ & $\begin{array}{l}\text { antiserum } \\
\text { to } 3489\end{array}$ & $\begin{array}{c}\text { M24 } \\
\text { typing } \\
\text { serum }\end{array}$ \\
\hline $\begin{array}{l}\text { Stock M-type } 12 \\
3651 \text {. } \\
3651 \text { var. } \\
3489 \text {. } \\
\text { Stock M-type } 24\end{array}$ & $\begin{array}{l}\text { T12+, M12+ } \\
\text { T12+, M12- } \\
\text { T12+-, M12-- } \\
\text { T12+, M12- } \\
\text { T4+, M24-+ }\end{array}$ & $\begin{array}{r}305 \\
130 \\
180 \\
215 \\
80\end{array}$ & $\begin{array}{l}++++ \\
+++ \\
+++ \\
+++ \\
+++\end{array}$ & $\begin{array}{c}0 \\
11 \\
+++ \\
+++ \\
+++\end{array}$ & $\begin{array}{c}4 \\
3 \\
+++ \\
++-1 \\
+-+\end{array}$ & $\begin{array}{c}+++ \\
+++ \\
16 \\
2 \\
+++\end{array}$ & $\begin{array}{c}+++ \\
+++ \\
+-+ \\
+++ \\
0\end{array}$ \\
\hline
\end{tabular}

\footnotetext{
* $0.02 \mathrm{ml}$ of a $10^{-4}$ dilution of a $5-\mathrm{hr}$ broth culture.

$\uparrow$ Number of colonies from $0.02 \mathrm{ml}$ of mixture after incubation for $5 \mathrm{hr}$.

$\ddagger$ Too numerous to count.
}

\section{The serum opacity reaction}

Many group-A streptococci give rise to opacity when incubated in the presence of horse serum, and this activity is believed to be due to a lipoproteinase produced by the streptococci (Krumweide, 1954; Rowen, 1961). It was at first thought that a positive serum-opacity reaction was a characteristic of M-negative cultures (Gooder, 1961; Köhler, 1963). Recently, Top and Wannamaker $(1968 a)$ have shown that in general this is not so, but that a genuine inverse relation does occur in type $12 ; \mathrm{T} 12+, \mathrm{M} 12+$ cultures are almost invariably negative in the test (SOR--), and most $\mathrm{T} 12+, \mathrm{M} 12-$ cultures are positive $(\mathrm{SOR}+$ ). The same authors (Top and Wannamaker, $1968 b$ ) have also established the existence of a number of immunologically distinct lipoproteinases; each enzyme is formed only by streptococci with a particular T-agglutination pattern, but some $\mathrm{T}$-agglutination patterns include streptococci with different lipoproteinases.

We tested a number of our cultures by the same opacity reaction procedure (table IV). None of the T12+, M12+ cultures isolated from patients in 1959-61 gave a positive reaction; in this respect they behaved like the stock 
M-positive type-12 culture and $\mathrm{T} 12+, \mathrm{M} 12+$ cultures from other sources. Sixteen $\mathrm{T} 12+, \mathrm{M} 12$ - cultures were tested, and were all SOR +; 13 of them had been isolated from patients in 1961-63, and 2 had been selected from SOR - cultures possessing the M-antigen 12 .

\section{TABLE IV}

Serum opacity reactions of 28 representative T-type-12 strains of streptococci in relation to the presence or absence of type-12 M-antigen

\begin{tabular}{|c|c|c|c|c|c|}
\hline \multicolumn{4}{|c|}{ Streptococcus strain } & \multirow{2}{*}{$\frac{\text { Antigenic structure }}{\mathrm{T} 12+, \mathrm{M} 12+}$} & \multirow{2}{*}{ Serum opacity reaction* } \\
\hline Stock typ & & . & . & & \\
\hline \multicolumn{4}{|c|}{10 Voorhout strains (1959-61). } & $\mathrm{T} 12+, \mathrm{M} 12+$ & - \\
\hline 3621 var. & . & . & . & $\begin{array}{l}\mathrm{T} 12+, \mathrm{M} 12+ \\
\mathrm{T} 12+, \mathrm{M} 12-\end{array}$ & 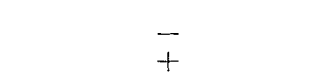 \\
\hline 3651 . & : & . & . & $\begin{array}{l}\text { T12+, M12+ } \\
\text { T12+, M12-- }\end{array}$ & $\overline{+}$ \\
\hline \multicolumn{4}{|c|}{13 Voorhout strains $\hat{T}^{\dagger}(1961-63)$} & $\mathrm{T} 12+, \mathrm{M} 12-$ & + \\
\hline
\end{tabular}

* Serum opacity reaction: $+=$ positive; $-=$ negative.

$\dagger$ Including strain 3489.

TABLE V

The specific neutralisation of serum opacity reactions produced by $\mathrm{T} 12+, \mathrm{MI2}-$ strains in the presence of $T 12+, M 12-$ antiserum

\begin{tabular}{|c|c|c|c|c|c|}
\hline \multicolumn{2}{|c|}{ Streptococcus } & \multicolumn{4}{|c|}{ Serum opacity reaction* in presence of } \\
\hline Strain & $\begin{array}{l}\text { Antigenic } \\
\text { structure }\end{array}$ & $\begin{array}{c}\text { no } \\
\text { antiserum }\end{array}$ & $\begin{array}{l}\text { M12 typing } \\
\text { serum }\end{array}$ & $\begin{array}{c}\text { antiserum } \\
\text { to strain } \\
3621\end{array}$ & $\begin{array}{c}\text { antiserum } \\
\text { to strain } \\
3489\end{array}$ \\
\hline $\begin{array}{l}3621 \text {. } \\
3621 \text { var. } \\
3489 \text { - } \\
\text { Stock M-type } 9 \\
\text { Stock M-type 2 }\end{array}$ & $\begin{array}{l}\text { T12+, M12+ } \\
\text { T12+, M12- } \\
\text { T12+, M12- } \\
\text { T9+, M9+ } \\
\text { T2+, M2+ }\end{array}$ & $\begin{array}{l}- \\
+ \\
+ \\
+ \\
+\end{array}$ & $\begin{array}{l}-\vec{t} \\
+ \\
+ \\
+\end{array}$ & $\begin{array}{l}- \\
+ \\
+ \\
+\end{array}$ & $\begin{array}{l}- \\
- \\
+ \\
+ \\
+\end{array}$ \\
\hline
\end{tabular}

$*+=$ Positive; $-=$ negative.

The ability of $\mathrm{T} 12+, \mathrm{M} 12$ - strains to produce opacity was specifically inhibited by antiserum to strain no. 3489 (T12+, M12-), but not by antiserum to strain no. 3621 (T12+, M12+); however, the antiserum to no. 3489 did not inhibit the serum opacity reaction produced by two serologically unrelated streptococci (table V). 
It seemed likely that if the serum opacity reaction could be used as a plate test it might provide a convenient marker for the selection of $\mathrm{T} 12+, \mathrm{M} 12-$ variants in cultures in which they formed only a small minority. Preliminary experiments showed that SOR + cultures produced halos around colonies in pour-plates of 5 per cent. horse serum agar. Eleven of the Voorhout cultures with the M12 antigen were examined in this way. They were subcultured directly into infusion broth from the blood-agar slopes on which the cultures had been stored and the broth cultures were used to seed pour-plates of serum agar. Seven of the 11 cultures yielded one or more colonies with halos on these plates. In this manner, all 7 cultures yielded SOR + strains that were found to be $\mathrm{T} 12+, \mathrm{M} 12-$; these strains were therefore identical serologically with the variants that had been obtained from three of the cultures by selection of colonies on blood agar.

These findings strengthened the presumption that the presence in the same culture of individual streptococci with different $\mathrm{M}$-antigens was not due to impurity of the original material. No other instance of a mixture of types was encountered in several hundred Voorhout cultures, and it is almost inconceivable that 7 out of 11 cultures, isolated at different times in the course of $2 \mathrm{yr}$, should all be inadvertent mixtures of the same two types.

In an effort to resolve the question finally, six of the $\mathrm{T} 12+, \mathrm{M} 12+$ cultures were re-examined as follows. Each was subcultured three times in succession from a single colony on a blood-agar plate before being transferred to a bloodagar slope in a screw-capped bottle. After incubation overnight, these cultures were stored at room temperature. Subcultures were made weekly on to the surface of blood-agar plates and into broth from which pour-plates were made in 50 per cent. horse serum agar. Both series of cultures were examined for colonial variants. Variants without M12 antigen were obtained from several plates, but all except one gave a negative serum opacity reaction. Unfortunately the single $\mathrm{T} 12+, \mathrm{M} 12$ - variant that was SOR + did not grow in normal human blood and so could not be examined in the bactericidal test; however, its serum opacity reaction was inhibited by the antiserum to strain 3489 (T12+, M12-).

\section{Lysogenicity}

A number of the Voorhout cultures were included in a survey of lysogenicity in group-A streptococci, carried out in collaboration with Professor L. W. Wannamaker. They were tested for the ability to form phage plaques on a lawn of a single indicator strain (K56).

Eleven of the $\mathrm{T} 12+, \mathrm{M} 12+$ cultures from Voorhout were examined, and all were found to be lysogenic. None of the T12+, M12 - strains tested, whether selected in the laboratory from $\mathrm{T} 12+, \mathrm{M} 12+$ cultures or isolated from patients, formed any plaques on the indicator. Further tests were carried out in which the supernatants of broth cultures of $\mathrm{T} 12+, \mathrm{M} 12+$ cultures, and phage from $\mathrm{T} 12+, \mathrm{M} 12+$ cultures propagated on $\mathrm{K} 56$, were spotted on to lawns of $\mathrm{T} 12+, \mathrm{M} 12$ - cultures. Although there was evidence that phage adsorption took place, no plaques were seen. It appeared, therefore, that 
$\mathrm{T} 12+, \mathrm{M} 12-$ cultures were resistant to the action of the phage carried by $\mathrm{T} 12+, \mathrm{M} 12+$ cultures, and were therefore not non-lysogenic variants. They may have been infected with a defective phage, but treatment with ultraviolet light failed to activate it.

The variant we believe to have arisen from the M-type-12 streptococcus at Voorhout thus differs from its parent in three ways: it forms a different $\mathrm{M}$-antigen, it possesses a type-specific enzyme that produces opacity in horse serum, and it does not carry a phage active against strain K56 (table VI).

TABLE VI

Lysogenicity of T-type-12 streptococci in relation to presence of the M-antigen 12 and production of the serum opacity reaction

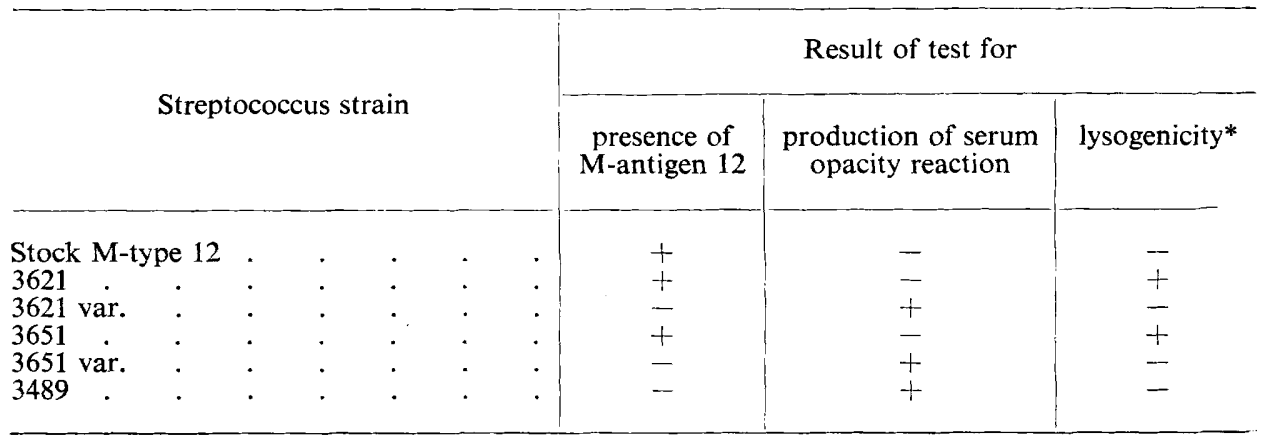

* Lysogenicity: $+=$ plaques formed on a lawn of strain $\mathrm{K} 56 ;-=$ no plaques formed on a lawn of strain K56.

\section{Discussion}

Two streptococci with the same T-antigen but with different M-antigens were found in the population of Voorhout. One was a member of M-type 12, and the other was a strain with an M-antigen that appears to have been hitherto unrecognised. Although there is no doubt that the second strain had an $\mathrm{M}$-antigen, final proof that it is a member of a new M-type is still lacking. Antisera to it gave no precipitation with extracts of the type strains for all known M-types, but they gave a rather weak precipitin reaction with extracts of the homologous organism; the new strain also failed to precipitate with any of the available $\mathbf{M}$-antisera, but these did not include antisera for M-types $8,13,27,28,32,34,38,40,42$ and 44.

The M-type-12 streptococcus was a rather infrequent cause of sore throat during the first $2 \mathrm{yr}$ of the Voorhout investigation, and was not seen in the succeeding $3 \mathrm{yr}$. The new strain appeared in the $2 \mathrm{nd} \mathrm{yr}$, and was found in nearly one-third of all cases of sore throats in years 3, 4 and 5. The fact that it was also present as a minority-population in 7 of 11 cultures of the M-type-12 streptococcus isolated in years 1 and 2 suggests that what we had observed was not simply the disappearance of one streptococcal strain and its replacement by an unrelated one, but rather that the new strain had arisen as a variant of the M-type-12 strain, and had spread in the population, whilst the parent strain had been unable to do so. 
We believe that such a change in the M-antigen of a group-A streptococcus has not been recorded before, although the situation observed by Wiley and Wilson (1961) in relation to the M-antigens 14 and 51 bears some relation to it. In the latter case, however, the two antigens are usually formed by the same streptococcus, though the proportion of each may vary widely in different cultures, and in individual colonies in the same culture. All streptococci with $\mathrm{M}$-antigen 14 appear to have some type-51 M-antigen, but a few pure M-type-51 cultures have been seen (Dr G. G. Wiley, personal communication). The Voorhout streptococci had one M-antigen or the other, but never both; and the two strains differed from each other not only antigenically but also in the ability to produce opacity in serum and in lysogenicity.

The apparent loss of $\mathrm{M}$-antigen by streptococci that have been carried for long periods of time by convalescent patients might include instances in which there is a partial or complete replacement of one M-antigen by another. Indeed, among the cultures isolated serially from patients by Rothbard and Watson (1948), there was one set in which an M-type-14 strain had apparently become untypable during convalescence. Re-examination of these cultures by Wiley showed that the strain isolated during convalescence had only the M-antigen 51 . Further studies of the antigenic composition of group-A streptococci from long-term carriers, concentrating on the detection of changes in antigenic specificity rather than on a loss of antigen, are now desirable.

It is interesting to consider the external influences that might have been responsible for the change we believe to have taken place in the M-type-12 streptococcus in Voorhout. This strain appears to have contained a small number of variants lacking the M12 antigen, and some of these variants had the ability to form an M-antigen with a different immunological specificity. Since $\mathrm{M}$-antigens have antiphagocytic activity, and antibody to them gives type-specific immunity to man, a variant with a different M-antigen might become predominant in a population in which immunity to the parent strain was high as a result of widespread infection.

With group-B streptococci (Lancefield, 1934; Curtis and Krause, 1964), and also with certain streptococci related to group F (Willers and Alderkamp, 1967), instances have been reported in which continued passage in broth in the presence of type-specific antiserum has resulted in the appearance of organisms without type-specific antigen. It is not known how these organisms survive the action of the antibody, or whether the antibody can affect the specificity of protein antigens synthesised by streptococci. The most likely action of antibody is, however, to select mutants with an altered specificity, although there is no evidence that among streptococci such selection, in the absence of phagocytic cells, is due to bactericidal activity.

The possibility that " new" M-types of group-A streptococci might arise or be selected in certain environments is attractive, and might provide an explanation of the difficulties encountered in typing streptococci isolated from skin lesions, particularly in communities in which pyoderma is very widespread and usually remains untreated for long periods of time. Few of these streptococci are identifiable with existing $\mathbf{M}$-antisera, and skin lesions have proved 
to be a rich source of new M-types, some of which appear to have a rather limited geographical distribution (Top et al., 1967; Parker et al., 1968; Potter et al., 1968).

There is no reason to believe that the antigenic change observed at Voorhout is the only one that can occur in M-type-12 streptococci. In a later investigation elsewhere in Holland we observed two organisms with the T-antigen 12; one had the type-12 M-antigen and was SOR-, and the other had the type-22 $\mathrm{M}$-antigen and was SOR + . When the $\mathrm{T} 12+, \mathrm{M} 12+$ cultures were screened on serum agar plates, colonies with halos were found that consisted of $\mathrm{T} 12+$, M22 + streptococci. Further details of this investigation will be published later.

The serum agar pour-plate technique used for the selection of SOR+ variants proved very successful with the Dutch type-12 strains. In other studies with streptococci of different types, more variable results have been obtained and this suggests that the plate method should be used cautiously until it is known that all such serum opacity reactions are attributable to the action of a similar enzyme.

The observation that the new Voorhout strain differed in lysogenicity from the original M-type-12 strain appears to provide an attractive starting-point for investigations of the mechanism of the supposed change in antigenic specificity. In Staphylococcus aureus, several changes in cultural characters have been made by lysogenic conversion (de Waart, Winkler and Grootsen, 1962; Rosendal, Bülow and Jessen, 1964; Jevons, John and Parker, 1966), and there is evidence that the ability to produce erythrogenic toxin by group-A streptococci is dependent on the presence of a temperate phage (Zabriskie, 1964), but no example of a change in the cellular antigens of streptococci or staphylococci as a result of lysogenisation has yet been recorded. In the laboratory, phage antibody "cures" streptococci of phage carriage, and this may be relevant because it was the new Voorhout strain that appeared to be non-lysogenic. Although the new strain adsorbs phage from the M-type-12 strain, it has not yet been possible to lysogenise it with the phage.

\section{SUMMARY}

During the long-term study of sore throat caused by group-A streptococci in a village, $\mathrm{M}$-positive members of type 12 disappeared and were replaced by streptococci that appeared to be M-negative variants of the original strain.

The new strain resembled the original M-type- 12 streptococcus in possessing the T-antigen of type 12, but further investigation showed that it was not M-negative; it had a hitherto undescribed $\mathrm{M}$-antigen. It also differed from the M-type-12 strain in having the ability to produce opacity in horse serum and in not being lysogenic for a phage active on the indicator strain K56.

A minority-population of the new strain was found in 7 of 11 cultures of the original M-type-12 streptococcus. This is taken as evidence that the new strain has arisen as a variant of the M-type-12 streptococcus. 


\section{REFERENCES}

Curtis, S. N., AND Krause, R. M. 1964. J. Exp. Med., 120, 629.

GOODER, $\mathrm{H}$

1961. J. Gen. Microbiol., 25, 347.

Goslings, W. R. O., Valkenburg, H. A., 1963. New Engl. J. Med., 268, 687.

BOTS, A. W., AND LORRIER, J. C.

Jevons, M. Patricia, John, Madeleine, 1966. J. Clin. Path., 19, 305. AND PARKER, M. T.

KJEMS, E.

KÖHLER, W.

1958. Acta path. microbiol. scand., 44, 429.

KrumweIde, Elma $189,275$.

Kuttner, ANN G., AND Lenert, T. F. . 1944. J. Clin. Invest., 23, 151.

LANCEFIELD, REBECCA C. . . . . 1934. J. Exp. Med., 59, 441.

,

1957. Ibid., 106, 525.

1962. J. Immun., 89, 307.

MAXTED, W. R., AND POTTER, ElizABeth

1967. J. Gen. Microbiol., 49, 119.

V.

OUCHTERLONY, Ö.

PARKer, M. T., BASSeTt, D. C. J., Maxted, W. R., and ARneaud, J. D.

Potter, Elizabeth V., Moran, AnN F., PoOn-King, T., ANd Earle, D. P.

Rosendal, KIrSten, Bülow, P., AND 1964. Nature, Lond., 204, 1222. JESSEN, $\mathbf{O}$.

Rothbard, S., AND Watson, R. F. $\quad$. 1948. J. Exp. Med., 87, 521.

ROWEN, R. . . . . . 1961. Ibid., 114, 807.

Swift, H. F., Wilson, Armine T., AND 1943. Ibid., 78, 127.

LANCEFIELD, REBECCA C.

TodD, E. W., AND LANCEFIELD, REBECCA 1928. Ibid., 48, 751. C.

TOP, F. H., JR, AND WANNAMAKER, L. W.

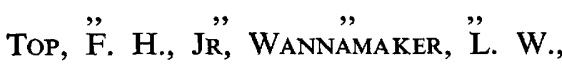
MAXTED, W. R., AND ANTHONY, B. F.

VAlkenburG, H. A., Goslings, W. R. O., BOTS, A. W., DE MOOR, C. E., AND LORRIER, J. C.

VALKenburg, H. A., HAVERKorn VAN RiJsewiJk, M. J., Goslings, W. R. O., DE MOOR, C. E., AND MAXTED, W. R.

DE WAart, J., Winkler, K. C., AND GroOTSEN, CA

WanNamaker, L. W., Denny, F. W., Perry, W. D., Siegel, A. C., AND RAMMELKAMP, C. $\mathrm{H}$.

Wiley, G. G., AND Wilson, ARmine T. 1961. J. Exp. Med., 113, 451.

Willers, J. M. N., AND Alderkamp, 1967. J. Gen. Microbiol., 49, 41. GEERTRUIDA H. J.

WILLIAMS, R. E. O.

WORMALD, P. J.

1958. Bull. Wld Hlth Org., 19, 153.

1956. J. Hyg., Camb., 54, 89.

ZABRISKIE, J. B.

1964. J. Exp. Med., 119, 761. 
STREPTOCOCCAL M-ANTIGEN VARIATION

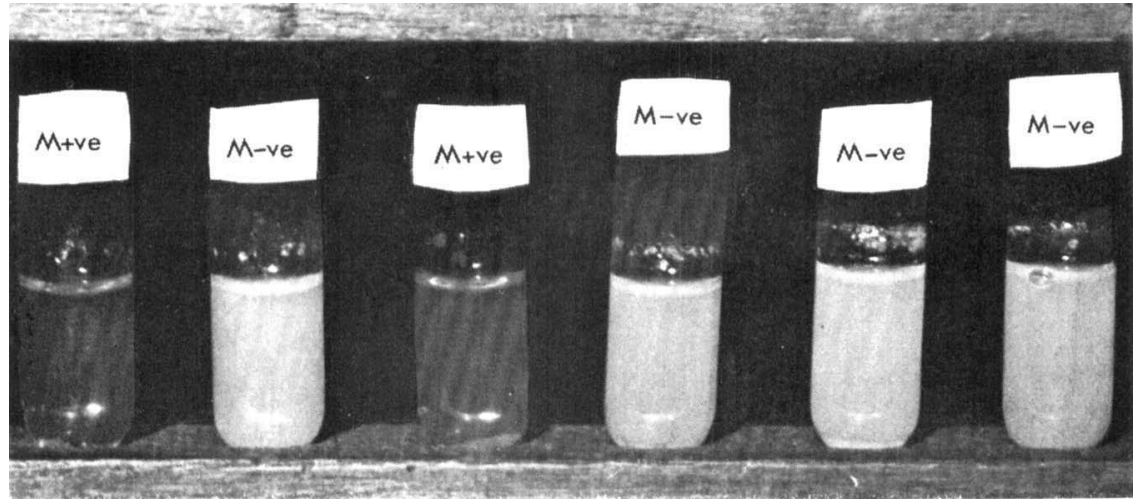

FIG. 1.--Serum opacity reaction in the tube test; cultures without M-antigen 12 give a positive result.

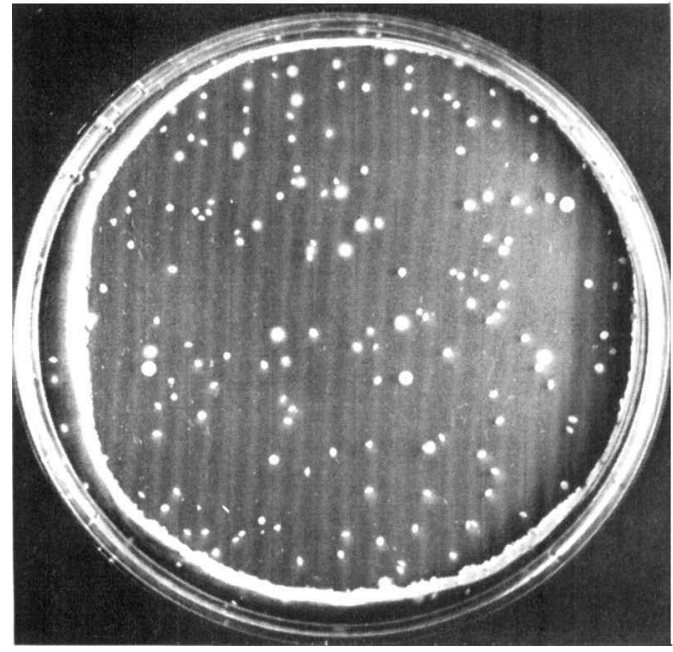

FIG. 2a.-Serum agar plate; about 25 per cent. of the colonies are surrounded by a halo. $\times c, \frac{2}{3}$.

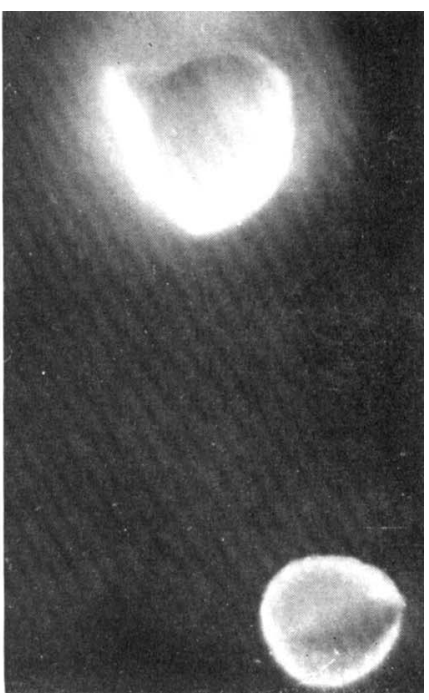

FIG. 2b.-Upper colony; positive reaction. Lower colony; negative reaction. $\times c .14$.

FIG. 2.-Serum opacity reaction in the plate test. 